\title{
Otizm Spektrum Bozukluğu Tanılı Çocuklara Yönelik Yoğun Davranışsal Uygulama Oturumlarına Hazırlık İşlemi Olarak 'Oturum-Öncesi Eşleştirme’
}

\author{
Prof. Dr. Gönül KIRCAALİ-İFTAR* \\ Maltepe Üniversitesi, Eğitimi Fakültesi, Özel Eğitim Bölümü, İstanbul / Türkiye, \\ gonuliftar@maltepe.edu.tr, ORCID: 0000-0001-7061-4364
}

\section{$\ddot{O} z$}

Yoğun davranışsal uygulama; otizm spektrum bozukluğu tanılı çocuklarla, uygulamalı davranış analizi ilkelerine dayalı olarak, haftada 20-40 saat süreyle ve ağırlıklı olarak ayrık-denemelerle öğretim düzenlemesiyle evde ya da kurumda yürütülen öğretim uygulamasıdır. Yoğun davranışsal uygulama ve ayrık-denemelerle öğretim, OSB tanılı öğrencinin uzun sürelerle öğretim etkinliğine katılmasını ve yerinde oturmasını; ayrıca, uygulamacının talep ettiği çok sayıda tepkiyi yerine getirmesini gerektirmektedir. Bu nedenle, yoğun davranışsal uygulamanın yürütüldüğü öğretim ortamı, öğretimi yürüten uygulamacı ve öğretimde yer alan araç-gereçler öğrenci için itici uyaran özelliği kazanabilmektedir. Dolayısıyla, yoğun davranışsal uygulama sırasında çeşitli davranış sorunlarıyla çok sık karşılaşılmaktadır. Öğrenciyle bağ kurmak, istenmeyen etkinliğin iticiliğini azaltma amacına hizmet eden bir öncül-temelli düzenleme olarak alanyazında yer almakta olup; oturum-öncesi eşleştirme, yoğun davranışsal uygulama için geliştirilmiş olan özel bir bağ kurma işlemidir. Oturum-öncesi eşleştirmede, öğrenci için yeni olan uygulama ortamı, uygulamacılar ve uygulama araç-gereçleri olumlu pekiştireçlerle eşleştirilerek öğrencinin ilk kez katılacağı öğretimin iticiliğini azaltıp öğrencinin öğretime sorunsuzca katılım olasılığını artırmak hedeflenir. Bu makalenin amacı, oturum-öncesi eşleştirmeye ilişkin 
alanyazında yer alan araştırmaları ve uygulama sürecini tanıtmaktır.

Anahtar Kelimeler: Otizm spektrum bozukluğu; Uygulamalı davranış analizi; Yoğun davranışsal uygulama; Ayrık denemelerle öğretim; Bağ kurma; Oturum-öncesi eşleştirme.

\title{
'Presession Pairing' as a Preparation Procedure for
}

\section{Comprehensive Behavioral Treatment Sessions for}

Children with Autism Spectrum Disorder

\begin{abstract}
Comprehensive behavioral treatment (CBT) is a practice carried out with children with autism spectrum disorder (ASD) following the principles of applied behavior analysis (ABA) at home or in a clinic for 20-40 hours per week and predominantly contains discrete-trial training (DTT) as the instructional format. CBT and DTT require the learner with ASD engage in the instructional activity and stay seated for prolonged periods of time as well as comply with the frequent requests of the implementer. Hence, the instructional environment, the practitioner, and the materials of the CBT may become aversive stimuli for the learner. Therefore, various behavioral problems are observed frequently during CBT. Building rapport with the learner is mentioned in the literature as an antecedent-based intervention for decreasing the aversiveness of the task demand whereas presession pairing is a special form of rapport building developed for CBT. During presession pairing, the novel educational environment, implementer, and materials are paired with positive reinforcers to decrease the aversiveness of the instruction that the learner encounters for the first time and eliminate problems to the greatest extent possible. The aim of the present manuscript is to address the research related to and implementation process of presession pairing.

Keywords: Autism spectrum disorder; Applied behavior analysis; Comprehensive behavioral treatment; Discrete-trial training; Rapport building; Presession paring.
\end{abstract}

\section{Extended Summary}

Applied behavior analysis (ABA) is an evidence-based practice for managing behavior problems of and teaching functional skills to individuals with autism spectrum disorder (ASD). Comprehensive behavioral treatment (CBT) is an ABA-based intervention carried out with young children with ASD at home or in a clinic for 20-40 hours per week. Discrete-trial training 
(DTT) is the main instructional format of CBT. CBT requires the learner with ASD engage in the instructional activity and stay seated for prolonged periods of time as well as comply with the frequent requests of the implementer. Hence, the instructional environment, the practitioner, and the materials of the CBT may become aversive stimuli for the learner. Therefore, significant behavioral problems are observed frequently during CBT.

Consequence-based strategies such as differential reinforcement are utilized widely for eliminating problems during CBT. However, consequence-based strategies alone may not be sufficient for solving persistent and severe problem behaviors of individuals with ASD. Hence, antecedent-based strategies are also recommended, especially for problem behaviors that have a function of escape from instruction. Building rapport with the learner is mentioned in the literature as an antecedent-based intervention for decreasing the aversiveness of the task demand and consequently managing learner problems.

\section{Presession Pairing}

Presession pairing is a special form of rapport building developed for CBT. During presession pairing, the novel educational environment, implementer, and materials are paired with positive reinforcers to decrease the aversiveness of the instruction that the learner encounters for the first time and eliminate problems to the greatest extent possible.

\section{Research on Presession Pairing}

A total of six studies, all carried out via single-subject methodology, have been identified in the literature related to the role of presession pairing arrangements for initiating CBT programs without problems. Lugo, King, Lamphere and McArdle (2017) examined the effectiveness of a behavioral skills training (BST) program on teaching presession pairing skills to practitioners effectively. All participants of the study were able to gain the presession paring skills in 3-to-8 BST sessions. Lugo, McArdle, King, Lamphere, Peck and Beck (2019) investigated the preferences of a 4-year-old girl with ASD regarding presession pairing prior to the onset of DTT, free play prior to the onset of DTT, or immediate onset of DTT conditions. The findings of the study suggested that the participant showed a preference for the presession pairing condition over the other conditions. 
The first experimental research examining the effects of presession pairing on the behaviors of individuals with ASD was conducted by Shillingsburg, Bowen and Shapiro (2014). The results of the study revealed that the participants of the study, two young boys with ASD, performed a higher number of social approach and a lower number of social avoidance behaviors when a presession pairing procedure was in effect. The results of the study conducted by Kelly et al. (2015) with three children with ASD showed that the participants exhibited fewer problem behaviors when instructional sessions were preceded by 2-to-4 min long presession pairing than when they were not. Shillingsburg, Hansen and wright (2019) analyzed the effects of presession pairing plus instructional fading with four young boys with ASD. The results of the study indicated that presession pairing implemented with instructional fading had all the participants start the program with very few problem behaviors. Cariveau et al. (2019) conducted a similar study with seven young girls with ASD. The independent variable of the study was a presession pairing intervention consisting of eight stages and accompanied with an instructional fading component. The findings of the study showed that this intervention was effective on reducing the problem behaviors of and increasing the instructional compliance of the participants.

\section{Implementation of Presession Pairing}

According to the author of this manuscript the presession pairing protocol developed by Cariveau et al. (2019) is more convenient than and according to the literature it is more efficient than the other protocols. Thus, the implementation stages of this protocol are presented below:

Stage 1: The learner is allowed to freely move around and access any reinforcer.

Stage 2: All the reinforcers are placed on the table and the learner is not allowed to take any reinforcer out of the table.

Stage 3: All the reinforcers are placed on the table and the learner is not allowed to take any reinforcer out of the table. If the learner stands near the table for $20 \mathrm{~s}$ or more, the practitioner guides the learner into the chair at the table.

Stage 4: The practitioner presents a single demand and immediately presents a controlling prompt. If the learner does not resist the prompt, a 1-min reinforcement interval is presented.

Stage 5: The practitioner presents a single demand and immediately presents a 
controlling prompt. If the learner does not resist the prompt, a half-min reinforcement interval is presented.

Stage 6: The practitioner presents a single demand and immediately presents a controlling prompt. If the learner does not resist the prompt, a half-min reinforcement interval is presented followed by a second demand.

Stage 7: The practitioner presents a single demand and immediately presents a controlling prompt. If the learner does not resist the prompt, a 15-sec reinforcement interval is presented followed by a second demand.

Stage 8: The practitioner presents a single demand and immediately presents a controlling prompt. If the learner does not resist the prompt, a 15-sec reinforcement interval is presented followed by two more demands.

\section{Conclusion}

The advantages of presession pairing can be summarized as follows:

1. Presession pairing may result in encountering fewer problems when a learner with ASD starts a new program such as CBT or starts to work with a novel practitioner.

2. Presession pairing might be effective with both high-functioning and low-functioning individuals with ASD.

3. Presession pairing can be claimed to be among the ethically preferable practices based on the fact that it is delivered without a need of a highly intrusive physical guidance.

4. Presession pairing is a procedure that can easily be implemented in one-to-one as well as group teaching environments.

5. There are research outcomes indicating that it is relatively easy and does not take much time to teach presession pairing to practitioners.

6. It can be recommended to utilize this procedure with all individuals with ASD or other developmental disabilities when they are to start a new program or instruction.

\section{Giriş}

Otizm spektrum bozukluğu (OSB), (a) sosyal iletişimde ve etkileşimde yetersizliklerle; (b) ilgilerde ve davranışlarda sınırlılık ve takıntılarla kendini gösteren karmaşık bir gelişimsel yetersizliktir (American Psychiatric Association, 2013). OSB tanısı alan bireylerde saldırganlık ve etkinliğe katılımı reddetme gibi önemli davranış sorunlarına oldukça sık rastlanmaktadır (Hill ve ark., 2014; Shillingsburg, Bowen ve Shapiro, 2014). Uygulamalı davranış 
analizine (UDA) dayalı öğretim ve davranış yönetimi uygulamalarının OSB tanılı bireylerin davranış sorunlarıyla başa çıkmadaki ve onlara işlevsel beceriler kazandırmadaki etkililiği, pek çok deneysel araştırma bulgusuyla ortaya konmuştur. Bu bulgulara kaynaklık eden araştırmalar, OSB alanındaki bilimsel dayanaklı uygulamaların derlendiği kapsamlı araştırma raporlarında da yer almaktadır (National Autism Center, 2015; Steinbrenner ve ark., 2020). National Autism Center (2015) tarafindan yayımlanan raporda, OSB'li bireylerle UDA'ya dayalı olarak yürütülen öğretim ve davranış yönetimi uygulamalarının etkililiğine ilişkin olarak alanyazında toplam 453 deneysel araştırma makalesi yer aldığı bildirilmiştir. Bu durum, UDA'nın OSB alanında yürütülen uygulamalar arasında bilimsel dayanakları en güçlü olan ve içinde pek çok odaklanmış uygulama barındıran bir kapsamlı uygulama olduğunu göstermektedir (Odom, Boyd, Hall ve Hume, 2009).

UDA, davranışsal yaklaşım içinde yer alan kuramların, özellikle edimsel koşullama kuramının laboratuvar ortamlarında ortaya koyduğu ilkeleri, eğitim ortamlarından iş ortamlarına değin tüm laboratuvar-dışı ortamlardaki insan ve hayvan davranışlarını değiştirmek amacıyla kullanan disiplindir. UDA'da öncelikle değiştirilecek -artırılacak, azaltılacak ya da kazandırılacak- gözlenebilir ve ölçülebilir hedef davranışlar belirlenir. Hedef davranışlara ilişkin benimsenen artırma, azaltma ya da kazandırma amacı, davranışların çevresel öncüllerini ve/veya sonuçlarını değiştirerek gerçekleştirilir. Ayrıca, davranışlar üzerinde meydana getirilmesi hedeflenen değişikliklere ilişkin olarak uygulama öncesinde, sırasında ve sonrasında gözlem verisi toplanarak, hedeflenen davranışsal değişimlerin meydana gelip gelmediği nesnel olarak değerlendirilir ve izlenir (Alberta ve Troutman, 2013; Catania, 2011).

Bir hedef davranışta istendik değişimi yaratmak amacıyla davranıştan sonra yer alan çevresel özelliklere ilişkin yapılan düzenlemelere sonuç-temelli (consequence-based) uygulamalar, davranıştan önce yer alan çevresel özelliklere ilişkin yapılan düzenlemelereyse öncül-temelli (antecedent-based) uygulamalar denir. Steinbrenner ve arkadaşları (2020) tarafından hazırlanan OSB' de bilimsel-dayanaklı uygulamalara ilişkin derleme raporunda, her biri sonuç-temelli bir uygulama olan pekiştirme, ayrımlı pekiştirme ve söndürme, OSB'li bireylere yönelik ayrı birer bilimsel dayanaklı uygulama olarak yer almaktadır. OSB'li bireylere yönelik öncül-temelli uygulamalarsa; (a) etkinliklerde, araç-gereçlerde ve akış planlarında uyarlama yapma, (b) seçim fir- 
satlarına yer verme, (c) programda yer alan etkinliklere ilişkin bilgilendirme ve hazırlık yapma, (d) etkinlik sırasında öğretim akışını ya da zorluğunu farklılaştırma, (e) ek araç-gereçlerle ya da uyaranlarla (ör., görsel destekler) çevresel zenginleştirme yapma, (f) ipucu ve pekiştirme sistemleri ile bunların sunumlarında uyarlama yapma olarak gruplandırılmaktadır. Öncül-temelli uygulamalar, tek başlarına ya da sonuç-temelli uygulamalarla birlikte kullan1labilmektedir (Smith, 2011; Sofarelli, 2018; Steinbrenner ve ark., 2020). Steinbrenner ve arkadaşları (2020) tarafindan hazırlanan raporda, OSB'li bireylerle yürütülen öncül-temelli uygulamaların etkililiğini gösteren 49 deneysel araştırmaya erişildiği; dolayısıyla, öncül-temelli uygulamaların yüksek düzeyde bilimsel-dayanağa sahip olduğu bildirilmiştir.

\section{Yoğun Davranışsal Uygulama}

Yoğun davranışsal uygulama (comprehensive behavioral treatment); OSB tanılı çocuklarla, UDA ilkelerine dayalı olarak, haftada 20-40 saat süreyle ve ev ya da kurum temelli olarak yürütülen kapsamlı uygulamadır. Yoğun davranışsal uygulamada öncelikle taklit, eşleme, oyun, alıcı dil, ifade edici dil becerileri gibi temel becerilerin öğretimine yer verilir. Ağırlıklı olarak, uygulamacı yönlendirmeli ayrık-denemelerle öğretim (discrete-trial training) düzenlemesiyle yürütülen yoğun davranışsal öğretimde, özellikle iletişim ve sosyal etkileşim becerilerinin geliştirilmesinde, firsat öğretimi gibi öğrenci yönlendirmeli doğal öğretim düzenlemeleri de kullanılır. Ayrıca, ilk firsatta akran etkileşimi düzenlemesi de programa eklenir ve yanı sıra, çocuğun bir yandan da yarı-zamanlı okulöncesi kaynaştırmadan yararlanması hedeflenir (Kırcaali-İftar, Kurt ve Kürkçüoğlu, 2019; Kırcaali-İftar, Kürkçüoğlu ve Kurt, 2018; Klintwall ve Eikeseth, 2014; Lovaas, 2003; Vismara ve Rogers, 2010). Yoğun davranışsal uygulamanın alanyazındaki en eski örneği Lovaas (2003) tarafindan geliştirilen ve Amerika Birleşik Devletleri başta olmak üzere dünyanın pek çok ülkesinde yaygın olarak uygulanan erken ve yoğun davranışsal eğitim/müdahale (early and intensive behavioral intervention) programıdır (Maurice ve Taylor; 2005; National Autism Center, 2015)

Çok sayıda deneysel ve nedensel-karşılaştırmalı araştırma, yoğun davranışsal uygulamanın OSB tanılı çocukların bilişsel, iletişimsel ve uyumsal becerilerinde, daha az yoğun uygulamalara, davranışsal olmayan uygulamalara ya da eklektik uygulamalara kıyasla daha fazla ilerlemelere yol açtığını göstermektedir (National Autism Center, 2015; Peters-Scheffer, Didden, Korzilius ve Sturmey, 2011). National Autism Center (2015) tara- 
findan hazırlanan derlemede, yoğun davranışsal uygulamanın OSB'li çocuklar üzerindeki etkililiğine ilişkin olarak toplam 41 deneysel araştırma makalesine ulaşıldığı rapor edilmiştir. Bu araştırmaların bulguları, yoğun davranışsal uygulamanın OSB'li çocuklara oyun becerilerinin, öğrenmeye hazırlık becerilerinin, akademik becerilerin, iletişim becerilerinin, ileri bilişsel işlev becerilerinin, kişiler-arası etkileşim becerilerinin ve devinsel becerilerin kazandırılmasında; ayrıca, OSB'ye özgü belirtilerin ve davranış sorunlarının azaltılmasında etkili olduğu yönündedir. Öte yandan, benzer özelliklerdeki yoğun davranışsal uygulama programlarına devam eden OSB tanılı çocukların ilerleme hızlarında önemli farklar olduğu da görülmektedir.

Yoğun davranışsal uygulama programlarındaki başarıyı yordayan değişkenlerin belirlenmesi, hangi özelliklerdeki OSB tanılı bireylerin program sonucunda nasıl bir ilerleme gösterebileceklerine ilişkin öngörü geliştirme açısından önemli görünmektedir. Alanyazında bu amaçla yürütülen en kapsamlı çalışmada Perry ve arkadaşları (2011), yoğun davranışsal uygulama programlarından göreli olarak daha fazla ve daha az yararlanan OSB'li çocukların özelliklerini belirlemek amacıyla, 2-7 yaş arasında olup toplum-temelli bir yoğun davranışsal uygulama programına devam eden OSB tanılı 332 çocuğun gelişimini izlemiş ve değerlendirmişlerdir. Araştırmanın bulguları, programa başladığında daha küçük yaşta ve daha yüksek işlev düzeyinde bulunan; ayrıca, daha uzun süre programda kalan çocukların en fazla ilerlemeyi gösterdikleri yönündedir. En az ilerleme gösteren çocukların özelliklerininse, programa başladıkları sırada, programa başlayan diğer çocukların özelliklerinden farksız olduğu ortaya çıkmıştır. Bu bulgulardan hareketle, performans düzeylerine bakılmaksızın, OSB tanılı çocukların tümüne yoğun davranışsal uygulama gibi bir bilimsel dayanaklı programdan yararlanma şansı verilmesi gerektiği çıkarsaması yapılabilir.

Yoğun davranışsal uygulamada ağırlıklı olarak, gelişim yetersizliğ olan bireylerle yaygın olarak kullanılan ayrık-denemelerle öğretim süreci kullanılmaktadır. Ayrık-denemelerle öğretim süreci, OSB tanılı bireylerle yürütülen bilimsel dayanakları en yüksek uygulamalar arasında yer almakta olup; Steinbrenner ve arkadaşları (2020) tarafından gerçekleştirilen derleme çalışmasında, ayrık-denemelerle öğretimin OSB'li çocuklar üzerindeki etkililiğini gösteren 38 deneysel araştırma olduğu bildirilmiştir. Ayrık-denemelerle öğretim için, taklit ya da alıcı dil gibi her bir beceri alanına özgü, çok sayıda hedef davranıştan ve kolaydan zora doğru küçük adımlarla 
ilerleyen aşamadan oluşan bir müfredat geliştirilmiştir. Ayrık-denemelerle öğretim sırasında uygulamacı, öğrenciye öğretmeyi planladığı hedef davranışa ilişkin olarak bire-bir öğretim formatında arka arkaya tepki firsatları düzenler. Her bir tepki firsatına 'deneme' adı verilir. Her bir denemede uygulamacı önce bir ön uyaran sunar. Bu ön uyaran bir soru, bir yönerge, bir hareket, bir araç, bir görsel ya da bunların birkaçının birlikte sunumu olabilir. Ön uyaranın ardından uygulamacı gerektiği kadar ipucu kullanarak öğrencinin hedef davranışı yapmasını, yani doğru tepkide bulanmasını sağlar. Örneğin, uygulamac1 'Böyle yap' deyip bir eliyle 'bay-bay' jesti yapar ve hemen ardından öğrencinin başat elini tutup havaya kaldırarak öğrenciye 'bay-bay' jesti yaptırır. Uygulamacı öğrencinin ipuçlu tepkisinin ardından olumlu pekiştirmeye yer verir. Pekiştirme işleminin sona ermesinin ardından da uygulamacı yeni bir deneme başlatır. Ayrık-denemelerle öğretim oturumlarında yanlışsız öğretim sürecine yer verilerek ipuçları giderek silikleştirilir ve son aşamada tümüyle ortadan kaldırılır. Böylece öğrenci ön uyaranın varlığında bağımsız olarak doğru tepkide bulunmaya başlar. Öğrencinin ipuçsuz doğru tepkileri ölçütü karşılar düzeye ulaştığında, pekiştirme seyrekleştirilerek edinilen hedef davranışın kalıcılığı sağlanır; genelleme oturumları düzenlenerek de hedef davranışın farklı araçlarla, farklı ortamlarda vb. sergilenme olasılı̆̆ artırılır (Cariveau ve ark., 2019; Kırcaali-İftar ve ark., 2019; Lovaas, 2003; Shillingsburg ve ark., 2014; Vismara ve Rogers, 2010).

Yoğun davranışsal uygulama ve bu öğretim uygulamasında yer alan ayrık-denemelerle öğretim, OSB tanılı öğrencinin uzun sürelerle öğretim etkinliğine katılmasını, belirli sürelerle yerinde oturmasını ve uygulamacının talep ettiği çok sayıda tepkiyi yerine getirmesini gerektirir. Bu nedenle, yoğun davranışsal uygulamanın yürütüldüğü öğretim ortamı, öğretimi yürüten uygulamacı ve öğretimde yer alan araç-gereçler öğrenci için itici uyaran özelliği kazanabilir. Dolayısıyla, yoğun davranışsal uygulama sırasında; öğretime katılmayı reddetme, öfke nöbeti gösterme ya da kendini uyarıcı davranış sergileme gibi davranış sorunlarılyla çok sık karşılaşılmaktadır (Carbone, Morgenstern, Zecchin-Tirri ve Kolberg, 2010; Kelly, Axe, Allen ve Maguire, 2015; Shillingsburg ve ark., 2014; Shillingsburg, Hansen ve Wright, 2019). Öğretim sırasında karşılaşılan bu ve benzeri davranış sorunları, öğretimin etkililiğini ve verimliliğini düşürebilmektedir (Lugo, King, Lamphere ve McArdle, 2017). Örneğin; Güleç-Aslan, Kırcaali-İftar ve Uzuner (2009), bir yoğun davranışsal uygulama programı olan Otistik Çocuklar İçin Davranışsal Eğitim Programı'nın (OÇIDEP) OSB tanılı bir çocukla yürütülme sürecini, 
nitel araştırma bağlamında incelemişlerdir. Araştırmacılar, OÇIDEP uygulamasının özellikle ilk iki ayında araştırmanın katılımcısı olan OSB'li çocukta önemli davranış sorunları (ör., ağlama, yerinde oturmak istememe vb.) ve öğretimsel sorunlar (ör., bazı becerilerde edinimin gecikmesi, çocuğun dikkatini etkinliğe vermemesi vb.) gözlendiğini belirtmişlerdir.

Alanyazında, yukarıda belirtilen türdeki davranış sorunlarıyla başa çıkmak için genellikle ayrımlı pekiştirme ve olumsuz pekiştirme gibi UDA'ya dayalı sonuç-temelli uygulamalara başvurulduğu belirtilmektedir (Alberta ve Troutman, 2013). Sonuç-temelli uygulamalar pek çok durumda işe yaramakla birlikte, OSB tanılı bireylerin önemli bir bölümünde bu tür davranış sorularının çözümünün oldukça uzun bir zaman aldığı; bazılarındaysa sorunların hiçbir zaman tümüyle çözülemediği de alanyazında belirtilmekteedir (Kelly ve ark., 2015; McGill, 1999; Shillinghsburg ve ark., 2014; 2019).

\section{Băg Kurma}

McGill (1999), OSB tanılı bireylerle çalışırken davranış sorunlarıyla başa çıkmada sonuç-temelli düzenlemelerin yanı sıra öncül-temelli düzenlemeler de yapmayı önermektedir. McGill'e göre, özellikle işlevi istenmeyen etkinlikten kaçma olan davranış sorunlarıyla başa çıkmada, istenmeyen etkinliğin iticiliğini azaltmak büyük önem taşımaktadır. Öğrenciyle bağ (rapport) kurmak, istenmeyen etkinliğin iticiliğini azaltma amacına hizmet eden bir öncül-temelli düzenleme olarak alanyazında yer almaktadır. McLaughlin ve Carr (2015), iki kişi arasında kurulan bağı, iki kişi arasındaki ilişkinin niteliği olarak betimlemişlerdir. Davranışsal açıdan ele alındığında bağ kurma, bireyin sosyal etkileşime yönelik motivasyonunu artırmak ve davranış sorunları sergileme olasılığını azaltmak amacıyla ortam düzenleme ve ilişki kurma olarak betimlenmektedir (Cariveau ve ark., 2019; Lugo ve ark., 2017; Shillingsburg ve ark., 2014, 2019; Taylor ve Fisher, 2010). Herhangi bir sosyal etkileşim sırasında iki kişi arasında güçlü bir bağın olduğuna ilişkin davranışsal göstergeler; karşısındakine fiziksel olarak yaklaşma, karşısındakiyle göz kontağı kurma, karşısındakine doğru dönme, karşısındakiyle fiziksel temasta bulunma ve gülümseme olarak siralanmaktadır (Ingvarsson, 2020).

McLaughlin ve Carr (2015), gelişim yetersizliği olan katılımcılar ile bakım verenleri arasındaki bağın niteliğini değerlendirmek ve bu veriler 1şığında davranış sorunlarıyla başa çıkmaya yönelik çok bileşenli bir uygulama tasarlamak amacıyla iki çalışmadan oluşan bir araştırma gerçekleştir- 
mişlerdir. Birinci çalışmada araştırmacılar, önce katılımcı-bakım veren çiftleri arasındaki bağı değerlendirmiş; ardından, katılımcıların davranış sorunlarının, bağın niteliği ve beceri taleplerinin etkileşimi çerçevesinde işlevsel analizini yapmışlardır. Bulgular, bağın niteliği ile davranış sorunları arasında ters ilişki olduğunu göstermiştir; daha açık bir ifadeyle, bağın niteliği düştükçe, davranış sorunları artmıştır. İkinci çalışmada, A-B-A-B modeline göre tasarlanan tek-denekli bir deneysel araştırma kapsamında, katılımcı-bakım veren çiftleri arasındaki bağın niteliğini artırmaya yönelik olarak çok bileşenli bir uygulama yürütülmüştür. Uygulamanın birinci aşamasında bakım verenlerin katılımcılara izler-olmayan pekiştirme yapmaları; ikinci aşamasında, katılımcıların iletişimsel girişimlerine duyarlı tepkilerde bulunmaları; üçüncü aşamasındaysa, katılımcılarla karşılıklı sıra almaları sağlanmıştır. Uygulama sonrasında, birinci araştırmada yer alan bakım verenlerin varlığında katılımcıların davranış sorunlarında azalma ve etkinliği tamamlama düzeylerinde artış gözlenmiştir. Bu bulgular, gelişim yetersizliğine sahip bireylerle etkileşen bakım verenlerin nitelikli bağ kurmalarının ne denli önemli olabileceğini gösteren ilk örneklerden biri olarak alanyazında yerini almıştır.

Parsons, Bentley, Solari ve Reid (2016), bağ kurmada önemli bir bağımsız değişken olduğunu düşündükleri terapistle aşinalık değişkeninin etkilerini, ileri derecede gelişim yetersizliğine sahip yetişkinlerin katılımcı olduğu bir araştırmayla değerlendirmişlerdir. Araştırmada, katılımcıların yeni terapistlerle aşina olmalarını sağlamak üzere çok basamaklı bir uygulama yürütülmüştür. Birinci basamakta, yeni terapist aşina terapistin de bulunduğu ortamda katılımcıyla, katılımcının favori etkinlikleri çerçevesinde etkileşmiş; ikinci basamakta, yeni terapist ve aşina terapist dönüşümlü olarak katılımcıyla hedef beceriler üzerinde çalışmış; izleyen basamaklardaysa yeni terapist oturumların giderek daha fazla bölümünde öğretim sunarken, aşina terapist giderek öğretim ortamının dışına çıkmıştır. Bulgular, yürütülen aşinalık uygulamasının ileri derecede gelişim yetersizliğine sahip yetişkin katılımcılarda etkinliğe katılım davranışlarını artırdığını ve yüksek hoşnutluğa yol açtığını göstermiştir.

Shireman, Lerman ve Hillman (2016) ise zihin yetersizliği bulunmayan ve yaşları 21-27 arasında olan OSB tanılı üç yetişkine, OSB tanılı çocuklarla oyun bağlamında sosyal etkileşimde bulunma becerilerini, davranışsal beceri öğretim süreciyle kazandırmışlardır. Davranışsal beceri öğretim sürecinde OSB'li yetişkinlere kazandırılması hedeflenen beceriler şunlardır: (a) en az 
her 10 saniyede bir uygun oyun becerisine model olma, (b) çocuğun sosyal etkileşimini sözel olarak pekiştirme, (c) 30 saniyede bir yiyecek sunma, (d) çocuğun her bir talebini yerine getirme, (e) tüm davranış sorunlarını görmezden-duymazdan gelme. Araştırmada tek-denekli deneysel araştırma modellerinden denekler-arası çoklu başlama modeli kullanılmış olup araştırma boyunca bağ kurma yoklamalarına yer verilmiştir. Araştırmanın bulguları, davranışsal beceri öğretiminin OSB'li yetişkin katılımcıların hedef sosyal etkileşim becerilerini edinmeleri üzerinde, OSB'li çocuk katılımcılarınsa yetişkinle kurdukları sosyal etkileşim düzeyi üzerinde etkili olduğunu göstermiştir. Yetişkin-çocuk arasındaki bağa ilişkin yoklama verileri de yürütülen deneysel uygulama sürecinin, aralarındaki mesafeyle ölçülen yetişkin-çocuk arasında kurulan bağda ilerlemelere yol açtığı yönündedir. Oturum-öncesi eşleştirme (presession pairing), yoğun davranışsal uygulama için geliştirilmiş olan özel bir bağ kurma işlemidir. Aşağıdaki bölümde oturum-öncesi eşleştirmenin özellerine ve bilimsel dayanaklarına ilişkin bilgiler yer almaktadır.

\section{Oturum-Öncesi Eşleştirme}

Oturum-öncesi eşleştirmede, öğrenci için yeni olan uygulama ortamını, uygulamacıları ve uygulama araç-gereçlerini olumlu pekiştirmeyle eşleştirerek öğrenciyle bağ kurmak hedeflenmektedir. Böylece, öğrencinin ilk kez deneyimleyeceği öğretimin iticiliğini azaltıp öğrencinin öğretime sorunsuzca katılım olasılığını artırmak amaçlanmaktadır (Carbone ve ark., 2010; Kelly ve ark., 2015; Lugo ve ark., 2017, 2019; Shillingsburg ve ark., 2014). Oturum-öncesi eşleştirme süreci, alanyazında, uygulamacının ve uygulama ortamının genelleşmiş pekiştireç haline getirilmesi süreci olarak da betimlenmektedir (Ensor, 2019).

Bu makalede, oturum-öncesi eşleştirmeye ilişkin kapsamlı bir kaynak taramasına yer vererek, uygulamacıların OSB'li öğrencilerle yürüttükleri öğretim ve davranış yönetimi uygulamalarını iyileştirmelerine katkıda bulunmak, araştırmacıların da bu konuda araştırma tasarlamaları için esin kaynağı olmak amaçlanmaktadır. Dolayısıyla, izleyen bölümlerde oturum-öncesi eşleştirme uygulamasına ilişkin alanyazında yer alan araştırmalar ayrıntılı olarak tanıtılmakta ve oturum-öncesi eşleştirme uygulama sürecinin nasıl yürütülebileceği anlatılmaktadır.

\section{Oturum-Öncesi Eşleştirmeye İlişsin Araştırmalar}

OSB'li çocuklara yönelik yoğun davranışsal uygulama programlarının 
sorunsuzca başlatılması ve yürütülmesi amacıyla geliştirilmiş olan oturum-öncesi eşleştirme düzenlemesine ilişkin olarak yürütülen araştırmaları belirlemek amacıyla internette bir alanyazın taraması yapılmıştır. Taramada 'presession pairing' ve 'rapport building' anahtar sözcükleri kullanılmıştır. Ayrıca, en yakın tarihli kaynaklardan başlanarak konuyla ilgili kaynakların kaynakçaları da gözden geçirilmiştir. Yapılan tarama ve gözden geçirme çalışmaları sonucunda oturum-öncesi eşleştirmeye ilişkin altı araştırma makalesine ulaşılmıştır.

Lugo ve arkadaşları (2017) tarafindan yürütülen araştırmada oturum-öncesi eşleştirme becerilerinin uygulamacılara etkili şekilde öğretimi amaçlanmıştır. Lugo ve arkadaşları (2019), Lugo ve arkadaşları (2017) tarafindan geliştirilen oturum-öncesi eşleştirme protokolüne ilişkin olarak OSB tanılı bir katılımcının tercihlerini değerlendirmişlerdir. Oturum-öncesi eşleştirmenin OSB'li çocukların öğretime katılım davranışları üzerindeki etkilerini değerlendiren alanyazındaki ilk deneysel araştırmaysa Shillingsburg ve arkadaşları (2014) tarafindan yürütülmüştür. Kelly ve arkadaşları (2015), her bir yoğun davranışsal uygulama oturumundan önce yer verilen oturum-öncesi eşleştirmenin OSB'li çocuklar üzerindeki etkilerini deneysel süreçte değerlendirmişlerdir. Shillingsburg ve arkadaşları (2019) ve Cariveau ve arkadaşları (2019) ise, oturum-öncesi eşleştirme ile öğretimsel girdiyi artırma (instructional fading) uygulamalarının birlikte kullanımının OSB'li çocuklar üzerindeki etkilerini, benzer protokoller çerçevesinde incelemişlerdir. Aşağıda, bu araştırmaların her birinin özellikleri ayrıntılı olarak açıklanmaktadır.

Lugo ve arkadaşları (2017) tarafindan, bir üniversite bünyesindeki uygulama biriminde OSB tanılı küçük çocuklara hizmet vermekte olan altı uygulamacıyla, oturum-öncesi eşleştirme becerilerini kazandırmak amacıyla, eşzamanlı olmayan denekler arası çoklu başlama modeline göre tasarlanan tek-denekli bir deneysel araştırma yürütülmüştür. Araştırmanın deneysel uygulamasında; sözel anlatım, model olma ve rol oynama aşamalarından oluşan davranışsal beceri ögretim süreciyle katılımcılara oturum-öncesi eşleştirme becerilerinin öğretimi yapılmıştır. Öğretimi yapılan beceriler; öğrenciyle fiziksel yakınlık kurma, öğrenciye sözel övgü sunma, öğrencinin sesletimlerini tekrarlama, öğrencinin oyun davranışlarını taklit etme, öğrencinin oyun davranışları üzerine konuşma, öğrenciye nesne sunma ve bir oyuncağın işlevini değiştirerek öğrenci için yeni bir etkinlik yaratmadır. Bu becerilerden oluşan oturum-öncesi eşleştirme uygulamasını yürüten uygula- 
maciların her birine, her oturumdan sonra performans geri-bildirimi sunulmuştur. Araştırma sonunda tüm katılımcıların oturum-öncesi eşleştirme becerilerini edindikleri belirlenmiştir. Öte yandan, ölçüte ulaşmak için gerekli performans geri-bildirim oturumu sayısı açısından katılımcılar arasında farkl11ıklar olduğu da saptanmıştır. Katılımcıların ölçütü karşılamaları en az 3, en fazla 8 oturumda gerçekleşmiştir.

Lugo ve arkadaşları (2019), 4 yaşında bir OSB'li kız öğrencinin, ayrık-denemelerle öğretim öncesinde oturum-öncesi eşleştirmeye katılma, ayrik-denemelerle öğretim öncesinde serbest oyun oynama ve doğrudan ayrık-denemelerle öğretime başlama koşulları arasındaki tercihlerini değerlendirmişlerdir. $\mathrm{Bu}$ araştırmada öğrenciye sunulan oturum-öncesi eşleştirme uygulaması, Lugo ve arkadaşları (2017) tarafından geliştirilen protokol çerçevesinde yürütülmüştür. Araştırmanın bağımlı değişkenleri, araştırma koşullarına ilişkin link (ör., poster) seçimi yapma ve sözel kendini uyarıcı davranışlarda bulunma olarak belirlenmiştir. Link seçimine ilişkin araştırma bulguları, katılımcı OSB'li çocuğun oturum-öncesi eşleştirme koşulunu diğer koşullara kıyasla daha fazla tercih ettiğini gösterir niteliktedir. Öte yandan, katılımcının sözel kendini uyarıcı davranışlarında azalma meydana gelmesi açısından koşullar arasında farklılık gözlenmemiştir. Araştırmacıların da belirttiği gibi, bu bulguların, daha fazla katılımcının yer aldığı ve deneysel kontrollü değerlendirmelerin yapıldığ 1 deneysel araştırmalarla sınanmasına gereksinim vardir.

Oturum-öncesi eşleştirmenin OSB'li birey davranışları üzerindeki etkilerine ilişkin olarak alanyazında yer alan ilk deneysel araştırma Shillingsburg ve arkadaşları (2014) tarafindan yürütülmüş̧ür. Bu araştırmada, oturum-öncesi eşleştirmenin, 3 ve 7 yaşlarındaki OSB tanılı iki erkek çocuğun ayrık-denemelerle öğretim oturumları sırasındaki sosyal yaklaşma (ör., çağrılınca masaya gelme) ve sosyal kaçınma (ör., masadan kalkma) davranışları üzerindeki etkileri incelenmiştir. Araştırmada tek-denekli araştırma modellerinden A-B-A modeli kullanılmıştır. A evresinde çocuktan taklit, eşleme, tekli yap-boz takma gibi basit beceri taleplerinde bulunulurken; B evresinde eşleştirme terapisti ve talep terapisti dönüşümlü olarak çocukla çalışmıştır. Eşleştirme terapisti hiçbir talepte bulunmaksızın önceden belirlenmiş etkili pekiştireçler ve çocuğun ilgi gösterdiği başka araç-gereçler çerçevesinde çocukla etkileşirken; talep terapisti A evresindeki gibi çalışmaya devam etmiştir. Araştırmanın ikinci A evresinde her iki terapist de dönüşümlü olarak 
çocuktan çeşitli beceri taleplerinde bulunmuşlardır. Araştırma bulguları, her iki katılımcı çocuğun da gerek B evresinde gerekse ikinci A evresinde eşleştirme terapistiyle çalışırken daha fazla sosyal yaklaşma ve daha az sosyal kaçınma davranışı sergilediğini göstermiştir. Bu bulgular, öğretim ortamında yürütülen oturum-öncesi eşleştirmenin OSB tanılı bireylerde davranış sorunlarını azaltıp etkinliğe katılımı artırdığını neden-sonuç ilişkisi bağlamında ortaya koyma açısından önemlidir.

Kelly ve arkadaşları (2015), biri 9, ikisi 11 yaşlarında OSB tanılı üç çocukla oturum-öncesi eşleştirmenin etkilerine ilişkin tek-denekli deneysel bir araştırma yürütmüşlerdir. Katılımcı çocukların davranış sorunlarının işlevlerini belirlemek amacıyla gerçekleştirilen işlevsel analiz, başlıca işlevlerin etkinlikten kaçma ya da etkinlikten kaçma ve ilgi elde etme olduğunu göstermiştir. Ayrıca, sistematik değerlendirmelerle, her çocuk için etkili pekiştireçler belirlenmiştir. Araştırmada denekler-arası çoklu başlama modeli kullanılmış olup, başlama düzeyi evresinde yürütülen ayrık-denemelerle öğretim oturumlarında oturum-öncesi eşleştirme yer almazken, deneysel uygulama evresinde yürütülen her bir ayrık-denemelerle öğretim oturumundan önce 2-4 dakika süreyle oturum-öncesi eşleştirme uygulamasına yer verilmiştir. Oturum-öncesi eşleştirme sırasında uygulamacı çocuğa neyle oynamak istediğini sorarak çocuğun seçtiği etkinliğe eğlenceli biçimde katılmıştır. Araştırma bulguları, oturum-öncesi eşleştirmeye yer verilen deneysel uygulama oturumlarında, katılımcı çocukların, başlama düzeyine kıyasla daha az davranış sorunu sergilediklerini ortaya koymuştur. Ayrıca, katılımc1ların oturum-öncesi eşleştirme uygulamasının yer aldığı öğretim oturumlarındaki akademik performanslarında da hafif bir yükselme olmuştur. $\mathrm{Bu}$ sürecin ardından, yeni becerilerin öğretimine ilişkin öğretim oturumları düzenlenmiş ve bu oturumlardan önce de oturum-öncesi eşleştirmeye yer verilmiştir. Oturum-öncesi eşleştirmeden sonra yürütülen yeni beceri öğretim oturumlarında katılımcı çocukların hiç davranış sorunu sergilemedikleri ve akademik performanslarında deneysel uygulama düzeyinde ya da daha fazla artışlar olduğu saptanmıştır. Bu araştırmanın bulguları etkileyici olmakla birlikte, her öğretim oturumundan önce 2-4 dakika süreyle oturum-öncesi eşleştirmeye yer vermek, öğretim zamanından önemli bir kayıp olarak da görülmektedir (Shillingsburg ve ark., 2019). Aşağıda, bu gerekçeyle oturum-öncesi eşleştirme uygulamasının aşamalı olarak sonlandırıldığı deneysel uygulamaların etkililiğinin sınandığı iki araştırma yer almaktadır. 
Shillingsburg ve arkadaşları (2019) tarafından yürütülen tek-denekli bir deneysel araştırmada, oturum-öncesi eşleştirme ile öğretimsel girdiyi artırma düzenlemeleri birlikte kullanılmıştır. Araştırmanın katılımcıları, ikisi 3, ikisi 4 yaşında olan OSB tanılı dört erkek çocuktur. Araştırmaya başlandığında, çocukların tümü bir yoğun davranışsal uygulama programına yeni kaydolmuşlardır. Araştırmada eşzamanlı olmayan denekler arası çoklu başlama modeli kullanılmıştır. Araştırmanın birinci bağımlı değişkeni, her katılımcı için bireysel olarak belirlenmiş olan davranış sorunlarıdır (saldırganlık, yıkıcılık, ağlama, kendine zarar verme, tükürme ya da kaçma). Diğer bağımlı değişkenler, yerinde oturma ve terapiste yakın mesafede durmadır. Oturum-öncesi eşleştirme ve öğretimsel girdiyi artırmanın birlikte kullanıldığ deneysel uygulamanın ilk aşamasında öğretimsel girdi olmaksızın öğretim ortamı ve uygulamacı pekiştireçlerle eşleştirilmiştir. Ardından ayrik-denemelerle öğretim kapsamında öğretimsel girdilere yer verilmeye başlamış ve bu girdiler aşamalı olarak artırılmıştır. Son aşamadaysa oturum-öncesi eşleştirme olmaksızın yalnızca ayrık-denemelerle öğretim yürütülmüştür. Başlama düzeyi evrelerinde de deneysel uygulama evresinin son basamağıyla aynı sürece yer verilmiştir. Araştırma bulguları, oturum-öncesi eşleştirme ve öğretimsel girdiyi artırmanın birlikte kullanımıyla yürütülen deneysel uygulama evresinde katılımcı çocukların tümünün çok düşük düzeyde davranış sorunu, çok yüksek düzeyde yerinde oturma ve uygulamaciya yakın mesafede durma davranışı sergilediklerini göstermiştir. Katılımcıların deneysel uygulama sürecini ortalama 10,5 saatte tamamladıkları belirlenmiştir. Bu bulgular, oturum-öncesi eşleştirme uygulamasının OSB'li bireylerin yoğun davranışsal uygulamaya uygun şekilde ve sorunsuz katılımını sağlama açısından önemlidir.

Cariveau ve arkadaşları (2019) tarafından, yaş ortalamaları yaklaşık 35 ay olup sözel becerileri çok sınırlı olan OSB tanılı dokuz kız öğrenciyle tek-denekli bir deneysel araştırma yürütülmüştür. Araştırmada eşzamanlı olmayan denekler arası çoklu başlama modeli kullanılmıştır. Araştırmanın bağımlı değişkenleri; davranış sorunu sergileme (odayı terk etme girişiminde bulunma, araç-gereçleri kırma ya da firlatma, uygulamacıya yönelik saldırganlıkta bulunma), uygulamacinın talebini yerine getirme, uygulamaciya yakın mesafede ( $66 \mathrm{~cm}$ 'den daha yakın) durma ve sözel kendini uyarıcı davranış sergileme olarak belirlenmiştir. Araştırmanın bağımsız değişkeniyse, sekiz aşamalı bir oturum-öncesi eşleştirme uygulaması ile öğretimsel girdiyi artırma uygulamasının birlikte kullanıldığı düzenlemedir. Uygulamanın bi- 
rinci aşamasında öğrenci ortamda serbestçe dolaşabilmiş; nesne ve yiyecek-içecek pekiştireçlerinin tümüne, herhangi bir koşula bağlı olmaksızın dilediğince erişebilmiştir. Bu sırada uygulamacı öğrenciden herhangi bir talepte bulunmamıştır. İkinci aşamada pekiştireçler uygulamacının yanındaki masanın üzerine konmuştur. Üçüncü aşamada uygulamacı öğrenciyi masanın yanında duran sandalyeye oturmaya yönlendirmiş ama ısrarcı olmamıştır. Dördüncü aşamadan itibaren uygulamacı öğrenciden beceri talebinde bulunmaya, talebine ilişkin ipucu sunmaya ve uygun öğrenci tepkilerine bağl1 olarak pekiştirme yapmaya başlamıştır. Sekizinci aşamaya doğru talep sayısı giderek artmış ve pekiştirme süresi giderek kısalmıştır. Bir aşamadan diğerine geçiş ölçütü olarak, ilk üç aşamada davranış sorunu düzeyi, izleyen aşamalardaysa davranış sorunu düzeyi ile uygulamacıya yakınlık birlikte dikkate alınmıştır. Katılımcıların birinde başlama düzeyi verileri uygulamaya gerek olmadığ1 yönünde olduğu için, birinde de ek davranış sorunları bulunduğu için deneysel uygulama yürütülememiştir. Yedi katılımcıyla yürütülen deneysel uygulamanın bulguları, bu araştırmada yürütülen oturum-öncesi eşleştirme uygulamasının orta-yüksek etki büyüklüğü düzeyinde etkili oldugunu göstermiştir. Katılımcıların deneysel uygulamada izlenen sekiz basamaklı protokolün tümünü ortalama 6.5 saatte tamamladıkları belirlenmiştir. $\mathrm{Bu}$ bulgular, bu araştırmada yürütülen oturum-öncesi eşleştirme uygulamasının hem etkili hem de diğer araştırmalarda izlenen süreçlere kıyasla zaman açısından daha verimli bir uygulama olduğunu göstermiştir. İzleyen bölümde, bu protokolde yer alan uygulama basamakları açıklanmaktadır.

\section{Oturum-Öncesi Eşleştirme Uygulama Süreci}

Oturum öncesi eşleştirme uygulamasına başlamadan önce, öğrenci için etkili olan ve eğitim ortamında kullanılabilecek özellikteki pekiştireçler (ör., yiyecek-içecek, araç-gereç ya da etkinlik pekiştireçleri) bireysel olarak belirlenir (ör., Kırcaali-İftar ve ark., 2019). Öğrencinin katılacağı ilk oturumda bu pekiştireçlerden olabildiğince fazla sayıda ve çeşitte bulunması sağlanır. Genellikle ilk oturumda, herhangi bir koşula bağlı olmaksızın ve öğrenciden herhangi bir talepte bulunulmaksızın, öğrencinin dilediği pekiştirece dilediğ oranda erişmesine olanak tanınır (Cariveau ve ark., 2019; Lugo ve ark., 2017).

Yukarıda tanıtılan araştırmaların deneysel uygulama süreçlerinde görüldüğ̈̈ gibi, oturum-öncesi eşleştirme protokollerinde yer alan öğelerde ve basamaklarda farklılıklar bulunmaktadır. Bu protokoller içinde, Cariveau ve arkadaşları (2019) tarafından geliştirilmiş olan protokol, yazar tarafından 
işevurukluk ve uygulanabilirlik açısından diğerlerinden daha elverişli bulunmuştur. Ayrıca, bu protokol, OSB'li öğrencilerin davranış sorunlarını azaltmada ve etkinliğe katılımlarını artırmada etkili olduğu kadar, diğer protokollere kıyasla süre açısından daha verimlidir. Tüm bu nedenlerden dolayı, aşağıda, bu oturum-öncesi eşleştirme protokolünün aşamaları yer almaktadır (Cariveau ve ark., 2019; Shillingsburg, 2020):

1. Adım: Öğrenci ortamda serbestçe dolaşabilir; nesne ve yiyecek-içecek pekiştireçlerinin tümüne erişebilir. Davranış sorunu sergilemek pekiştireçlere erişimi engellemez. Uygulamacı öğrenciden herhangi bir talepte bulunmaz. Öğrencinin üç oturum üst-üste davranış sorunu sergilememesi durumunda bir sonraki aşamaya geçilir.

2. Adım: Bütün nesne ve yiyecek-içecek pekiştireçleri uygulamacıya yakın mesafedeki (ör., bir kol mesafesindeki) masanın üzerine yerleştirilir. Öğrenci masanın üzerindeki pekiştireçlere dilediğince erişebilir; ancak, bir pekiştireci masadan uzaklaştırma girişiminde bulunduğunda uygulamacı o pekiştireci masaya geri koyar. Davranış sorunu sergilemek pekiştireçlere erişimi engellemez. Uygulamacı öğrenciden herhangi bir talepte bulunmaz. Öğrencinin üç oturum üst-üste davranış sorunu sergilememesi durumunda bir sonraki aşamaya geçilir.

3. Adım: Bütün nesne ve yiyecek-içecek pekiştireçleri uygulamacıya yakın mesafedeki (ör., bir kol mesafesindeki) masanın üzerine yerleştirilir. Öğrenci masanın üzerindeki pekiştireçlere dilediğince erişebilir; ancak, bir pekiştireci masadan uzaklaştırma girişiminde bulunduğunda uygulamacı o pekiştireci masaya geri koyar. Davranış sorunu sergilemek pekiştireçlere erişimi engellemez. Öğrenci en az 20 saniye süreyle masaya bir kol mesafesindeki bir yerde durduğunda uygulamacı öğrenciyi masanın yanında duran sandalyeye oturmaya yönlendirir. Eğer öğrenci sandalyeye oturmaya direnç gösterirse uygulamacı 1 srar etmeyerek bu talebinden vazgeçer. Öğrencinin üç oturum üst-üste davranış sorunu sergilememesi durumunda bir sonraki aşamaya geçilir.

4. Adım: Uygulamacı öğrenciden bir öğretimsel talepte bulunur ve hemen ardından talebine ilişkin kontrol edici ipucu sunar. Ĕger öğrenci ipucuna direnç göstermezse, 1 dakika süreyle masadaki pekiştireçlerle etkileşmesine izin verilir. Öğrencinin üç oturum 
üst-üste davranış sorunu sergilememesi ve öğretimsel talebe en az $\% 80$ düzeyinde katılım göstermesi durumunda bir sonraki aşamaya geçilir.

5. Adım: Uygulamacı öğrenciden bir öğretimsel talepte bulunur ve hemen ardından talebine ilişkin kontrol edici ipucu sunar. Eğer öğrenci ipucuna direnç göstermezse, yarım dakika süreyle masadaki pekiştireçlerle etkileşmesine izin verilir. Öğrencinin üç oturum üst-üste davranış sorunu sergilememesi ve öğretimsel talebe en az \%80 düzeyinde katılım göstermesi durumunda bir sonraki aşamaya geçilir.

6. Adım: Uygulamacı öğrenciden bir öğretimsel talepte bulunur ve hemen ardından talebine ilişkin kontrol edici ipucu sunar. Eğer öğrenci ipucuna direnç göstermezse, yarım dakika süreyle masadaki pekiştireçlerle etkileşmesine izin verilir. Ardından uygulamacı öğrenciden yeni bir öğretimsel talepte bulunur ve hemen ardından talebine ilişkin kontrol edici ipucu sunar. Eğer öğrenci ipucuna direnç göstermezse, yarım dakika süreyle masadaki pekiştireçlerle etkileşmesine izin verilir. Öğrencinin üç oturum üst-üste davranış sorunu sergilememesi ve öğretimsel taleplere en az \%80 düzeyinde katılım göstermesi durumunda bir sonraki aşamaya geçilir.

7. Adım: Uygulamacı öğrenciden bir öğretimsel talepte bulunur ve hemen ardından talebine ilişkin kontrol edici ipucu sunar. Eğer öğrenci ipucuna direnç göstermezse, 15 saniye süreyle masadaki pekiştireçlerle etkileşmesine izin verilir. Ardından uygulamacı öğrenciden yeni bir öğretimsel talepte bulunur ve hemen ardından talebine ilişkin kontrol edici ipucu sunar. Eğer öğrenci ipucuna direnç göstermezse, 15 saniye süreyle masadaki pekiştireçlerle etkileşmesine izin verilir. Öğrencinin üç oturum üst-üste davranış sorunu sergilememesi ve öğretimsel taleplere en az \%80 düzeyinde katılım göstermesi durumunda bir sonraki aşamaya geçilir.

8. Adım: Uygulamacı öğrenciden bir öğretimsel talepte bulunur ve hemen ardından talebine ilişkin kontrol edici ipucu sunar. Eğer öğrenci ipucuna direnç göstermezse, 15 saniye süreyle masadaki pekiştireçlerle etkileşmesine izin verilir. Ardından uygulamacı öğrenciden yeni bir öğretimsel talepte bulunur ve hemen ardından talebine ilişkin kontrol edici ipucu sunar. Eğer öğrenci ipucuna 
direnç göstermezse, 15 saniye süreyle masadaki pekiştireçlerle etkileşmesine izin verilir. Ardından uygulamacı öğrenciden bir öğretimsel talepte daha bulunur ve hemen ardından talebine ilişkin kontrol edici ipucu sunar. Eğer öğrenci ipucuna direnç göstermezse, 15 saniye süreyle masadaki pekiştireçlerle etkileşmesine izin verilir. Öğrencinin üç oturum üst-üste davranış sorunu sergilememesi ve öğretimsel taleplere en az \%80 düzeyinde katılım göstermesi durumunda oturum-öncesi eşleştirme süreci sonland1rilır.

Cariveau ve arkadaşları (2019) tarafından gerçekleştirilen araştırmada, yukarıda belirtilen aşamalara ilişkin uygulama oturumlarının her biri 10 dakika sürmüştür. Dolayısıyla, oturum-öncesi eşleştirme sürecinin, bu ve benzeri basamaklara sahip bir protokole sadık kalarak, bir protokolden esinlenerek ya da birkaç protokolden bir sentez yaparak yaklaşı1k 10'ar dakikalık oturumlarla yürütülmesi önebilir. Uygulama sırasında, oturum-öncesi eşleştirmenin öğrenci davranışları üzerindeki etkileri yakından izlenmelidir. Eğer beklentilerin üzerinde davranış sorunları gözlenirse ve/veya bağ kurmaya ilişkin davranışların (ör., uygulamacıya yakın durma, uygulamacıyla göz kontağı kurma vb.) gelişimi gecikirse, uygulama süreci değerlendirilmelidir. $\mathrm{Bu}$ değerlendirmede, pekiştireçlerin yeterince etkili olup olmadığı ve uygulamanın alanyazına paralel şekilde yürütülüp yürütülmediği gibi değişkenler gözden geçirilmelidir.

\section{Sonuç}

Yoğun davranışsal uygulamaya başlayacak OSB tanılı çocuklarla bağ kurmak için geliştirilmiş olan oturum-öncesi eşleştirme işlemi, çocuk için yeni olan uygulama ortamını, uygulamacıları ve uygulama araç-gereçlerini olumlu pekiştirmeyle eşleştirmeyi hedeflemektedir. Böylece, çocuğun ilk kez karşılaşacağı öğretimin iticiliğini azaltıp öğretime sorunsuzca katılım olas1lığını artırmak amaçlanmaktadır (Carbone ve ark., 2010; Kelly ve ark., 2015; Lugo ve ark., 2017, 2019; Shillingsburg ve ark., 2014). Bu makalede tanitılan alanyazına dayalı olarak oturum-öncesi eşleştirme uygulamasının yararları şöyle özetlenebilir:

1. Oturum-öncesi eşleştirme, OSB tanılı öğrencilerin sıklıkla davranış sorunu sergiledikleri yoğun davranışsal uygulama gibi programlara başlama ya da aşina olunmayan uygulamacılarla çalışmaya başlama gibi durumlarda çok daha az sorun yaşanmasını sağlayabilir 
(ör., Shillingsburg ve ark., 2014, 2019).

2. Oturum-öncesi eşleştirme, hem işlevde bulunma düzeyi yüksek (Kelly ve ark., 2015), hem de düşük (Cariveau ve ark., 2019) olan OSB tanılı bireylerde etkili olabilir.

3. Oturum-öncesi eşleştirmenin, öğrenci bedeni üzerinde yüksek müdahale gerektiren fiziksel ipucu sunumuna gerek olmaksızın yürütülen bir uygulama olması nedeniyle (Cariveau ve ark., 2019), etik açıdan yeğlenmesi gereken uygulamalar arasında olduğu öne sürülebilir.

4. Oturum-öncesi eşleştirme, hem birebir eğitim ortamlarında (ör., Sofarelli, 2018), hem de grup eğitim ortamlarında (ör., Ensor, 2019) kolaylıkla yürütülebilecek özellikte bir uygulama özelliği göstermektedir.

5. Oturum-öncesi eşleştirmenin uygulamacılara öğretilmesinin göreli olarak kolay olduğu ve kısa sürdüğü yönünde araştırma bulguları vardır (ör., Lugo ve ark., 2017).

6. Oturum-öncesi eşleştirme işleminin yoğun davranışsal uygulamayla sınırlı olmadığ görüşünden hareketle, bu tür eşleştirme uygulamalarının yeni bir programa ya da öğretime başlayacak tüm OSB ya da başka bir gelişim yetersizliği tanılı bireylerle kullanılması önerilebilir (ör., Taylor, 2013).

Türkçe alanyazında oturum-öncesi eşleştirme uygulamasına ilişkin herhangi bir kaynak taraması ya da araştırma çalışmasına rastlanmamıştır. Dolayısıyla, bu makalenin, OSB'li bireylerle çalışan uygulamacılar ve bu konuda araştırma yürütecek araştırmacılar için öncülük etmesi umulmaktadır. Türkiye'de bu konuda başlatılacak uygulamaların ve araştırmaların, hem OSB'li öğrencilere sunulan hizmetlerin niteliğinin artması açısından, hem de UDA ve özel eğitim alanlarının gelişimi açısından önemli olduğu düşünülmektedir.

\section{Kaynakça}

Alberta, P. A. ve Troutman, A. C. (2013). Applied behavior analysis for teachers $(9$. baskı). Upper Saddle River, NJ: Pearson.

American Psychiatric Association (2013). Diagnostic and statistical manual of mental disorders (5. bask1). Arlington, VA: American Psychiatric Publishing.

Carbone, V. J., Morgenstern, B., Zecchin-Tirri, G. ve Kolberg, L. (2010). The role of the reflexive-conditioned motivating operation (CMO-R) during discrete trial instruction of children with autism. Focus on autism and other developmental disabilities, 25(2) 110-124.

Doi: $10.1177 / 1088357610364393$ 
Cariveau, T., Shillingsburg, M. A., Alamoudi, A., Thompson, T., Bartlett, B., Gillespie, S. ve Scahill, L. (2019). Journal of behavioral education, 29, 699-716. Doi: 10.1007/s10864-019-09340-x

Catania, A. C. (2011). Basic opreant contingencies: Main effects and side effects. W. W. Fisher, C. C. Piazza ve H. S. Roane, (Ed.), Handbook of applied behavior analysis içinde (34-54). New York: The Guilford Press.

Ensor, R. (2019). The impact of pairing on therapeutic rapport and treatment outcomes for children with autism. Yayımlanmamış yüksek lisans tezi, Faculty of Social Sciences, Brock University.

Güleç-Aslan, Y., Kırcaali-İftar, G. ve Uzuner, Y. (2009). Otistik Çocuklar İçin Davranışsal Eğitim Programı (OÇİDEP) ev uygulamasının bir çocukla incelenmesi [Investigating the home implementation of the behavioral intervention program for children with autism (OCIDEP) with one child]. Ankara Üniversitesi Eğitim Bilimleri Fakültesi Özel Ĕ̈itim Dergisi, 10(1), 1-25.

Hill, A. P., Zuckerman, K. E., Hagen, A. D., Kriz, D. J., Duvall, S. W., van Santen, J., Nigg, J., Fair, D. ve Fombonne, E. (2014). Aggressive behavior problems in children with Autism Spectrum Disorders: Prevalence and correlates in a large clinical sample. Research in Autism Spectrum Disorders, 8(9), 1121-1133.

Doi: 10.1016/j.rasd.2014.05.006

Ingvarsson, E. T. (2020). Social reinforcement in early intervention with children with ASD. https://storage.outreach.psu.edu/autism/75-Presentation_0.pdf adresinden edinilmiştir.

Kelly, A. N., Axe, J. B., Allen, R. F. ve Maguire, R. W. (2015). Effects of presession pairing on the challenging behavior and academic responding of children with autism. Behavioral Interventions, 30(2), 135-156.

Doi: 10.1016/j.rasd.2014.05.006.

Kırcaali-İftar, G., Kurt, O. ve Ülke-Kürkçüoğlu, B. (2019). Otistik çocuklar için davranışsal eğitim programı-OÇİDEP I (4. baskı). Ankara: Anı Yayıncılık.

Kırcaali-İftar, G., Ülke-Kürkçüoğlu, B. ve Kurt, O. (2018). Otistik çocuklar için davranışsal eğitim programı-OÇIDEP II (3. baskı). Ankara: Anı Yayıncılık.

Klintwall, L. ve Eikeseth, S. (2014). Early and intensive behavioral intervention (EIBI) in autism. V. B. Patel, V. R. Preedy ve C. R. Martin, (Ed.), Comprehensive guide to autism içinde (117-137). London: Springer.

Lovaas, O. I. (2003). Teaching individuals with developmental delays: Basic intervention techniques. Austin, Texas: Pro-ed.

Lugo, A. M., King, M. L., Lamphere, J. C. ve McArdle, P. E. (2017). Developing procedures to improve therapist-child rapport in early intervention. Behavior Analysis in Practice, 10(4), 395-401.

Doi: $10.1007 / \mathrm{s} 40617-016-0165-5$

Lugo, A. M., McArdle, P. E., King, M. L., Lamphere, J. C., Peck, J. A. ve Beck, H. J. (2019). Effects of presession pairing on preference for therapeutic conditions and challenging behavior. Behavior Analysis in Practice, 12(1), 188-193. Doi: 10.1007/s40617-018-0268-2.

Maurice, C. ve Taylor, B. A. (2005). Early intensive behavioral intervention for autism: Challenges and opportunities. W. L. Heward, T. E. Heron, N. A. Neef, S. M. Peterson, D. M. Sainato, G. Cartledge, R. Gardner III, L. D. Peterson, S. B. Hersh, ve J. C. Dardig (Ed.), Focus on behavior analysis in education içinde 
(31-47). Upper Saddle River, NJ: Pearson.

McGill, P. (1999). Establishing operations: Implications for the assessment, treatment, and prevention of problem behavior. Journal of Applied Behavior Analysis, 32(3), 393-418.

McLaughlin, D. M. ve Carr, E. G. (2015). Quality of rapport as a setting event for problem behavior: Assessment and intervention. Journal of Positive Behavior Interventions, 7(2), 68-91.

National Autism Center (2015). Findings and conclusions: National standards project, phase 2. Randolph, MA: Author.

Odom, S. L., Boyd, B. A., Hall, L. J. ve Hume, K. (2009). Evaluation of comprehensive treatment models for individuals with autism spectrum disorders. Journal of Autism and Developmental Disorders, 40(4), 425-436.

Doi: 10.1007/s10803-009-0825-1

Parsons, M. B., Bentley, E., Solari, T. ve Reid, D. H. (2016). Familiarizing new staff for working with adults with severe disabilities: a case for relationship building. Behavior Analysis in Practice, 9(3), 211-222.

Doi: 10.1007/s40617-016-0129-9

Perry, A., Cummings, A., Geier, J. D., Freeman, N. L., Hughes, S., Managhan, T., Reitzel, J. ve Williams, J. (2011). Predictors of outcome for children receiving intensive behavioral intervention in a large, community-based program. Research in Autism Spectrum Disorders, 5(1), 592-603.

Doi: 10.1016/j.rasd.2010.07.003

Peters-Scheffer, N., Didden, R., Korzilius, H. ve Sturmey, P. (2011). A meta-analytic study on the effectiveness of comprehensive ABA-based early intervention programs for children with Autism Spectrum Disorders. Research in Autism Spectrum Disorders, 5(1), 60-69.

Doi: $10.1016 /$ j.rasd.2010.03.011

Shillingsburg, M. A. (2020, Şubat). Putting social interaction at the heart of autism interventions: The importance of play and social communication. Association for Behavior Analysis International Autism Conference'da sunulan bildiri, Miami, Forida.

Shillingsburg, M. A., Bowen, C. N. ve Shapiro, S. K. (2014). Increasing social approach and decreasing social avoidance in children with autism spectrum disorder during discrete trial training. Research in Autism Spectrum Disorders, $8(11), 1443-1453$.

Doi: $10.1016 /$ j.rasd.2014.07.013

Shillingsburg, M. A., Hansen, B. ve Wright, M. (2019). Rapport building and instructional fading prior to discrete trial instruction: Moving from child-led play to intensive teaching. Behavior Modification, 43(2), 288-306.

Doi: 10.1177/0145445517751436

Shireman, M. L., Lerman, D. C. ve Hillman, C. B. (2016). Teaching social play skills to adults and children with autism as an approach to building rapport. Journal of Applied Behavior Analysis, 49(3), 512-531.

Doi: 10.1002/jaba.299

Smith, R. G. (2011). Developing antecedent interventions for problem behavior. W. W. Fisher, C. C. Piazza ve H. S. Roane, (Ed.), Handbook of applied behavior analysis içinde (297-316). New York: The Guilford Press. 
Sofarelli, R. M. (2018). Teacher-implemented presession pairing to improve classroom behaviors in public schools. Yayımlanmamış yüksek lisans tezi, College of Behavioral and Community Sciences, University of South Florida.

Steinbrenner, J. R., Hume, K., Odom, S. L., Morin, K. L., Nowell, S. W., Tomaszewski, B., Szendrey, S., McIntyre, N. S., Yücesoy-Özkan, S. ve Savage, M. N. (2020). Evidence-based practices for children, youth, and young adults with Autism. The University of North Carolina at Chapel Hill, Frank Porter Graham Child Development Institute, National Clearinghouse on Autism Evidence and Practice Review Team.

Taylor, B. A. (2013). Improving the social behavior of children with autism. A. Bondy ve M. J. Weiss, (Ed.), Teaching social skills to people with autism: Best practices in individualizing interventions içinde (1-24). New Castle, DE: Pyramid Educational Consultants.

Taylor, B. A. ve Fisher, J. (2010). Three important things to consider when starting intervention for a child diagnosed with autism. Behavior Analysis in Practice, $3(2), 52-53$.

Doi: $10.1007 /$ BF03391766

Vismara, L. A. ve Rogers, S. J. (2010). Behavioral treatments in autism spectrum disorder: What do we know? Annual Review of Clinical Psychology, 6, 447-468.

Doi: 10.1146/annurev.clinpsy.121208.131151 